\title{
Role of Education and Financial Market Development in Attracting Foreign Direct Investment Inflows in Pakistan
}

\author{
Haider Mahmood ${ }^{1}$, Muhammad Tanveer ${ }^{2}$ \\ ${ }^{1}$ Associate Professor, Department of Finance, College of Business Administration, Prince Sattam \\ Bin Abdulaziz University, Saudi Arabia \\ ${ }^{2}$ Prince Sultan University, Riyadh, Saudi Arabia
}

\begin{abstract}
This paper has investigated the role of education and Financial Market Development (FMD) on the Foreign Direct Investment (FDI) inflows in Pakistan from 1970-2019. In the short run, education has a positive effect on FDI inflows. $1 \%$ increasing of government's spending on education would increase $0.361 \%$ of FDI inflows in Pakistan. Moreover, the FMD has a positive effect on FDI inflows in the short run. 1\% increasing FMD may increase $0.0496 \%$ of FDI in the short run. Both education and FMD are supporting the FDI inflows in the short run. Comparatively, education shows a larger effect on FDI than that of FMD in the short run. However, FMD and government spending on education could not affect the FDI inflows in the long run. This paper recommends supporting education and financial markets to attract FDI inflows in Pakistan.
\end{abstract}

Keywords - FDI inflows, FMD, government spending on education, cointegration.

\section{Introduction}

Education is a global determinant that may support all macroeconomic performance variables in any country. Education is also essential for investment

DOI: 10.18421/TEM103-23

https://doi.org/10.18421/TEM103-23

Corresponding author: Haider Mahmood,

Associate Professor, Department of Finance, College of Business Administration, Prince Sattam Bin Abdulaziz University, Saudi Arabia.

Email: haidermahmood@hotmail.com

Received: 08 April 2021.

Revised: 13 July 2021.

Accepted: 19 July 2021.

Published: 27 August 2021.

(c) BY-NC-ND (C) 2021 Haider Mahmood \& Muhammad Tanveer; published by UIKTEN. This work is licensed under the Creative Commons Attribution-NonCommercialNoDerivs 4.0 License.

The article is published with Open Access at www.temjournal.com growth in a country. Enormously, it may help to attract foreign investors to a country for investment purposes. Educated labor is pre-requirement for an investment environment. Moreover, cheap educated labor is a prime target for foreign investors to increase the investment return by saving the labor cost and increasing invested capital productivity. On the other hand, FDI is a bright determinant of any developing country's economic growth [1]. For example, China grows faster than India. Due to a higher proportion of FDI on income in China than India and skilled cheap labor, it makes China attractive for foreign investments. On the other hand, the Microsoft industry transfer in India is a massive achievement that shows labor's capacity to handle such a high-tech industry. It shows a mature skilled labor force's availability due to educational achievement and a vast market for the software product. Hence, education and human capital may be claimed as the fundamental determinants of FDI inflows. A prime investment location in Pakistan, adequate resources, and a cheap labor force cannot attract an appropriate inflow of FDI. It may be due to low human capital formation in the country. Hence, we cannot ignore the role of education in developing human capital for any nation. The role of education needs researchers' and policymakers' attention to attract more FDI in any country.

Some other factors also determine a low level of FDI, i.e., political instability, the fragility of the economy, non-performing loans, policy weaknesses, central banks' political dependence, and weak social values. Hence, the independent financial and political conditions do matter to attract foreign investors. To some extent, these issues are faced by developing countries in common. On the other hand, developed countries have tackled them sensibly, ultimately bringing the ultimate mutual consequence in the shape of better economic growth for both home and host countries. In the relationship between democracy and FDI, Guillermo [2] argued that autocracy was more attractive to FDI inflows because autocrats face lower constraints and offer 
more freedom because less-constraint investors choose to invest in economies with autocratic structures. In the same line, Acharya [3] stated that India is the world's largest democracy with established judiciary system and receives about onehalf percent in FDI of total global investment. On the other hand, China being a communist country provides a stable political and economic environment to foreign investors and receives the bulk of FDI.

In another debate, Kapur and Ramamurthy [4] stated that political instability, weak infrastructure and regional differences of infrastructure, the inflexibility of labor laws, changes in government and commercial regulations, increased tax and tariff, and corruption were the leading causes of low FDI inflows. They corroborated that India attracted investment in the services sector despite some political volatility. Jakobsen and Indra [5] explained that democratic governments might use FDI as a tool of growth to protect local citizens' and organizations' rights and interests. Moreover, foreign investors are attracted to established competitive markets and to get high incentives. They further added that democracy in a country increases trade volume, which may increase FDI inflows. Mahmood [6] investigated the determinants of FDI in Bangladesh and found that GDP and democracy positively affected FDI. Hence, institutional quality helped to attract the FDI inflows in Bangladesh.

Berden et al. [7] stated that democracy significantly affected FDI inflows for the past few decades, and it has become a paramount concern and crucial topic of research. FDI inflows have become vital in the world economy. The growth rates of FDI flows are exceeded that of trade flows. They further stated that important determinants of FDI are Gross Domestic Product (GDP) and Democracy. They claimed that more democratic countries might attract more foreign investors because democracies could provide a stable environment and investment protection. Mancur [8] argued that democracy was more attractive to FDI because established democracies are credible, and this political credibility provides a more stable and attractive environment to foreign investors for investment. Jensen [9] explained federalism's impact concerning FDI and democracy relationships by saying that foreign investors primarily prefer political benefits to invest in economic benefits.

Odedokun [10] stated that non-democratic regimes were negatively related to FDI. Such regimes reduced capital formation and FDI inflows. It also increased inflation and worsened the balance of payment and balance of trade. Li and Resnick [11] said that democracy might improve legislative stability. Their research covered 52 countries to identify FDI and democracy relationships.
Democracy and property rights protected the stable FDI inflows. Shah and Masood [12] conducted an empirical investigation to see the effect of various determinants of FDI in Pakistan by applying the cointegration technique covering time series data of 1960-2000. They found that political stability, market size, and infrastructure were significant determinants of FDI inflows in Pakistan and provided specific policy implications that were further worthwhile to the policymakers and researchers.

Abbas et al. [13] argued that countries with better financial positions might target FDI more efficiently. Such economies have high GDP indicating progress and standard of living for the state. They also concluded the importance of GDP to efficient utilization of FDI. Nawaz et al. [14] found that exchange rates are caused by dictatorship and harm Pakistan's economy in terms of FDI inflows. Its main reasons were that a decrease in the local currency's value led to decreased purchasing power. Hsiao and Shen [15] examined the relationship between FDI and GDP. This study describes that GDP has a substantial impact on FDI, using the means of least square regressions. The outcome shows that GDP proved to be a significant and positive determinant for FDI inflows. Javed et al. [16] stated that foreign investors are like birds sensitive to go anywhere but attracted by the places where favorable conditions exist. They might become a financial source to revolutionize the economy and ultimately fulfill the country's monetary and capitalistic gap to accomplish cost-effective activities. The authors had applied cointegration and error-correction models for the study, which covered the duration from 1973 to 2011. It was found that the variable GDP was the most substantial interpreter of FDI in the rank of importance. Schneider and Frey [17] stated that a low level of inflation in a country encourages FDI. Low inflation increases FDI if the government may balance its budget and monetary policy by a central bank. Low inflation is a symbol of the smooth running of the country's policies. The high inflation rate may cause economic tension, an imbalanced government budget, and inappropriate central bank policy. These reduce the return on investment. Therefore, foreign investors are likely to invest in a low and stable inflation environment.

Ercakar [18] investigated the long-run relationship between FDI and inflation using annual data from 1970 to 2008 for Turkey. The estimates showed a negative relationship between inflation and FDI. Inflation in high-cost countries resulted in low-cost imports due to high wages and a rise in the local economy's raw material prices. In this connection, trade could substitute investments. Therefore, foreign investors usually prefer the economies for investment with a low and stable inflation rate. Chowdhry and 
Mavrotas [19] employed a causal relationship between FDI and GDP of three primary recipient developing countries of FDI and found bidirectional causality. Puri and Ritzema [20] stated that every progressing country was in a race to draw foreign investors' interest by framing such policies that provide a favorable investment environment and leniency in taxation matters.

After discussing various vital determinants of FDI, including FMD, investigated in the literature, the present study focuses on education and educational spending on FDI inflows. This investigation is scant in the literature, but few studies have highlighted the importance of educational variables in the FDI inflows' model. For instance, a seminal study conducted by Schneider and Frey [17] found that income and secondary education positively affected the FDI inflows. Larger share of an age group with secondary education would attract FDI inflows to better economic health. Iwai et al. [21] argued that educational investment was very important to attract multinational firms. The investment in education might improve labor quality, motivating multinational firms to make contracts with local labor. Wang and Wong [22] investigated the FDI and economic growth relationship controlling secondary education in analysis. They found that FDI could only accelerate economic growth if a country achieved a certain secondary education level. Moreover, they argued a need for quality education to comprehend the complementary relationship between education and FDI. Shahbaz et al. [23] investigated the role of FMD and education on FDI in France, controlling some other important determinants using a period 1965-2017, and found that France's education and transport infrastructure have supported the FDI inflows. However, the effect of FMD was found negative on FDI. In a dynamic analysis, Berrill et al. [24] investigated the moderating role of education on labor and entrepreneurship in the FDI inflows' model using an extensive panel of 75 countries from 2001-2005. The study found that FDI led to more jobs in the presence of moderating role of education but carried a negative effect on entrepreneurship. Alshubiri [25] investigated the effect of education spending on the FDI and found a positive effect of tertiary education spending on the FDI inflows.

There is an urgent need to understand that despite many such attractive policies, high trade volume, and flexible external policies, Pakistan cannot achieve the desired level of foreign investments. The question has varied answers. The immediate answer lies in some severe issues like education level and financial markets. Pakistan's two neighboring countries India and China, have attracted a significant proportion of foreign investment in their countries. Sharing the same geographical features, Pakistan could attract a low level of FDI inflows in the country, which may claim due to the lesser government's attention on the education sector and low level of financial services. Hence, it seems vital to test the effects of education and financial development on Pakistan's FDI inflows. Moreover, testing the role of education and FMD is scant in the FDI inflows' model. Hence, this present study tries to fill this literature gap by investigating a developing country Pakistan, using the maximum available data from 1970-2019.

\section{Methods}

Literature has signified many determinants of FDI inflows in any country. This present research focuses on the education and FMD in the FDI inflows' model in Pakistan. Following Alshubiri [25], the study utilizes the government spending on education percentage of Gross Domestic Product (GDP) as a proxy for education. The education reflects the stock of human capital, which is necessary to attract the FDI inflows in any country. Hence, a positive effect of education on FDI inflows may be hypothesized. Moreover, the FMD is a vital determinant of the macroeconomic performance of any investment, including FDI inflows [23]. Increasing FMD may indicate a better economic environment, which may attract the FDI for economic incentives, large market size, and more comfortable financial transactions. Since FMD facilitates financial transactions, foreign companies need a modern way to facilitate the financial transaction between their head offices and local destinations. Hence, a positive relationship may be hypothesized between FMD and FDI inflows. Considering the importance of both FMD and education, the hypothesized model is as follows:

$$
\mathrm{FDI}_{\mathrm{t}}=\mathrm{f}\left(\mathrm{EDU}_{\mathrm{t}}, \mathrm{FMD}_{\mathrm{t}}\right)
$$

$\mathrm{FDI}_{t}$ is reflecting the FDI inflows as a percentage of GDP. $E U_{t}$ is government spending on education as a percentage of GDP. It is a proxy of education in Pakistan. $\mathrm{FMD}_{\mathrm{t}}$ is a credit to private sector by the bank, which is a proxy for FMD. Annual data on FDI, FMD, and education are taken from World Bank [26] for 1970-2019.

In the estimation strategy, stationary would be tested by Augmented Dickey and Fuller (ADF) [27] test at first. The FDI inflows model is estimated by the Autoregressive Distributive Lag (ARDL) model developed by Pesaran et al. [28]. This technique works well in the same integration level or a mixed order of integration with first-difference stationary dependent and a mix of level and first-difference stationary in independent variables. We conduct a test proposed by Dickey and Fuller [27] to verify the unit root problem to ensure the condition mentioned above. The ARDL equation of the FDI inflows' model is as follows: 


$$
\begin{aligned}
& \quad \Delta F D I_{t}=a_{0}+a_{1} F D I_{t}+a_{2} E D U_{t}+a_{3} F M D_{t}+ \\
& \sum_{i=1}^{n} a_{4 i} \Delta F D I_{t}+\sum_{i=0}^{n} a_{5 i} \Delta E D U_{t}+ \\
& +\sum_{i=0}^{n} a_{6 i} \Delta F M D_{t}+e_{1 t}
\end{aligned}
$$

The Wald test for all coefficients of lagged level variables can be utilized to ensure the cointegration. The normalized coefficients can also be derived for long-run influences from equation 3. Further, coefficients of differenced variables of equation 3 can be estimated for short-run effects in the following Error Correction Model (ECM), where $\mathrm{ECT}_{\mathrm{t}-1}$ is the lagged error correction term. Its negative and significant coefficient also ensures the short-run relation.

$$
\begin{gathered}
\Delta F D I_{t}=c_{0} E C T_{t-1}+\sum_{i=1}^{n} c_{1 i} \Delta F D I_{t}+ \\
\sum_{i=0}^{n} c_{2 i} \Delta E D U_{t}++\sum_{i=0}^{n} c_{3 i} \Delta F M D_{t}+e_{2 t}
\end{gathered}
$$

The parameters of differenced variables are the short-run effects of education and FMD on the FDI inflows.

\section{Analyses and Discussions}

Table 1 shows the ADF results. All variables have unit roots at the level. However, all variables are non-stationary at their first differences. Hence, ARDL cointegration can be applied for further analyses.

Table 1. ADF test results

\begin{tabular}{cccc}
\hline Variable & None & Intercept & $\begin{array}{c}\text { Intercept } \\
\text { \& trend }\end{array}$ \\
\hline $\mathrm{FDI}_{\mathrm{t}}$ & -1.8654 & -2.0251 & -2.1611 \\
$\mathrm{EDU}_{\mathrm{t}}$ & 0.3415 & -2.3155 & -2.5827 \\
$\mathrm{FMD}_{\mathrm{t}}$ & -0.7632 & -2.3717 & -2.7611 \\
$\Delta \mathrm{FDI}_{\mathrm{t}}$ & $-4.8731^{*}$ & $-4.8273^{*}$ & $-4.7883^{*}$ \\
$\Delta \mathrm{EDU}_{\mathrm{t}}$ & $-6.3223^{*}$ & $-6.3209^{*}$ & $-6.2616^{*}$ \\
$\Delta \mathrm{FMD}_{\mathrm{t}}$ & $-5.7282^{*}$ & $-5.6889^{*}$ & $-5.6378^{*}$ \\
\hline
\end{tabular}

Note: * shows stationarity at $1 \%$.

Table 2 shows that F-value, calculated from a bound test, is 202664 . It is smaller than the critical value at a $10 \%$ level of significance. The range of lower and upper values is given in the bracket. Hence, evidence of cointegration is not found in the model by bound testing. However, the cointegration is proved through a negative and significant coefficient of $\mathrm{ECT}_{\mathrm{t}-1}$. Further, F-values generated by diagnostic tests are low, and their p-values are

\begin{tabular}{|c|c|c|c|c|}
\hline Variable & Parameters & SE & t-Statistic & P-value \\
\hline \multicolumn{5}{|c|}{ Long Run Results } \\
\hline $\mathrm{EDU}_{\mathrm{t}}$ & -0.2558 & 0.3759 & -0.6804 & 0.5001 \\
\hline $\mathrm{FMD}_{\mathrm{t}}$ & 0.0308 & 0.0223 & 1.3790 & 0.1754 \\
\hline $\mathrm{C}$ & 0.7266 & 0.6642 & 1.0940 & 0.2803 \\
\hline \multicolumn{5}{|c|}{ Short Run Results } \\
\hline$\Delta \mathrm{FDI}_{\mathrm{t}-1}$ & 0.2898 & 0.0337 & 8.6044 & 0.0000 \\
\hline$\Delta \mathrm{EDU}_{\mathrm{t}}$ & 0.3610 & 0.0816 & 4.4225 & 0.0001 \\
\hline$\Delta \mathrm{FMD}_{\mathrm{t}}$ & 0.0496 & 0.0171 & 2.8967 & 0.0060 \\
\hline $\mathrm{ECT}_{\mathrm{t}-1}$ & -0.1797 & 0.0228 & -7.8749 & 0.0000 \\
\hline \multicolumn{5}{|c|}{ Diagnostics } \\
\hline $\begin{array}{c}\text { F- Value (Boun } \\
\text { Test) }\end{array}$ & Inc 2.2664 & $\begin{array}{c}10 \% \\
(3.17- \\
4.14)\end{array}$ & $\begin{array}{c}5 \% \\
(3.79- \\
4.85)\end{array}$ & $\begin{array}{c}1 \% \\
(5.15- \\
6.36)\end{array}$ \\
\hline $\begin{array}{l}\text { Hetero } \\
\text { scedasticity }\end{array}$ & \multicolumn{2}{|c|}{1.7969} & \multicolumn{2}{|c|}{0.1237} \\
\hline $\begin{array}{l}\text { Serial } \\
\text { Correlation }\end{array}$ & \multicolumn{2}{|c|}{0.2071} & \multicolumn{2}{|c|}{0.8137} \\
\hline Functional Forn & \multicolumn{2}{|c|}{0.5324} & \multicolumn{2}{|c|}{0.5973} \\
\hline Normality & \multicolumn{2}{|c|}{3.8158} & \multicolumn{2}{|c|}{0.1484} \\
\hline
\end{tabular}
sufficiently high. Therefore, the model is out of any econometric problem, and it is reasonable to interpret.
Table 2. Estimated FDI Inflows Model through ARDL

In the short-run results, a negative and significant parameter of $\mathrm{ECT}_{\mathrm{t}-1}$ is showing the existence of short-run and alternatively long-run relationships in the model. Further, the coefficient of $\mathrm{ECT}_{\mathrm{t}-1}$ is showing the convergence of short-run disequilibrium towards long-run equilibrium in approximately five years and seven months $(1 / 0.1797 * 12$ months). Moreover, the one-year's lag of FDI has a positive effect on the recent FDI inflows in Pakistan. It reflects that existing foreign investors are reinvesting in their projects and providing information to other investors to invest in Pakistan in the short time of one year. Moreover, it also narrates that incoming FDI could positively affect the following year's foreign investment environment.

In the short run, education has a positive effect on FDI. The elasticity coefficient shows that $1 \%$ increasing on educational spending by the government would increase $0.361 \%$ of FDI inflows in Pakistan. This result corroborates that increasing education improves human capital in Pakistan and helps the investment environment for FDI inflows in the short run. This is also corroborated by Schneider and Frey's [17] finding, who found that secondary education has a positive effect on FDI. Moreover, the FMD has a minute but positive effect on FDI in the short run. A $1 \%$ increasing FMD may increase $0.0496 \%$ of FDI inflows in Pakistan. This result indicates that increasing FMD increases income and aggregate demand in the country, which improves the space for further investment in turn. 
In the long run results, education has an insignificant effect on the FDI inflows in Pakistan. It means that education is not supporting the investment environment, and human capital is not mature enough in Pakistan to attract FDI inflows in the long run. It also corroborates the fact that a long-term investment in education may be required to develop country's human capital to attract foreign investment. Human capital is insufficient in the country to support the investment environment for foreign investors. Moreover, the FMD also carries an insignificant effect on the FDI inflows in the long run. It means that the country's financial market is not mature enough to support the transactions of foreign investors.

\section{Conclusion}

The financial markets and human capital are essential indicators of a smooth investment environment in any developing country. They may play a significant role in attracting FDI inflows in the country. Education may play a vital role in human capital development to support the investment of a country. This research investigates the role of FMD and education spending on the FDI inflows in Pakistan using the period 1970-2019. ARDL cointegration has been used for the data analysis. Long and short-run relationships have been found in the model. In the short run, education has a positive effect on the FDI, and 1\% increasing educational expenditure may increase the $0.361 \%$ of FDI inflows. Hence, increasing education is improving human capital for the promotion of FDI inflows in the short run. The FMD also positively affects the FDI inflows in the short run with a subtle effect, and $1 \%$ increase in FMD may increase by 0.0496 of FDI inflows in Pakistan. So, increasing FMD is corroborating a good investment environment in the country, which may attract foreign investors' attention for investments. In the short run, the lag of FDI inflows also positively affects the recent FDI inflows with the statistically significant coefficient of one-year lag effect. However, educational spending and FMD could not affect the FDI inflows in the long run. Hence, there is an urgent need to increase government spending on education in Pakistan to develop sufficient human capital for a country's smooth investment environment. Moreover, financial markets also need the government's attention, which may boost local and foreign investments in the country.

\section{References}

[1]. Mahmood, H., \& Chaudhary, A. R. (2009). Application of endogenous growth model to the economy of Pakistan: A cointegration approach. Pakistan Journal of Commerce and Social Sciences (PJCSS), 2, 16-24.

[2]. O'donnell, G. (1978). Reflections on the patterns of change in the bureaucratic-authoritarian state. Latin American Research Review, 13(1), 3-38.

[3]. Acharya, A. (1998). The Open temple. Director, 52(5), 71-71.

[4]. Kapur, D., \& Ramamurti, R. (2001). India's emerging competitive advantage in services. Academy of Management Perspectives, 15(2), 20-32.

[5]. Jakobsen, J., \& De Soysa, I. (2006). Do foreign investors punish democracy? Theory and empirics, 1984-2001. Kyklos, 59(3), 383-410.

[6]. Mahmood, H. (2018). An investigation of macroeconomic determinants of FDI inflows in Bangladesh. Academy of Accounting and Financial Studies Journal, 22(1), 1-7.

[7]. Berden, K., Bergstrand, J. H., \& Etten, E. V. (2014). Governance and Globalization. The World Economy, 37 (3), 353-386.

[8]. Olson, M. (1993). Dictatorship, democracy, and development. American political science review, 87(3), 567-576.

[9]. Jensen, N. M. (2003). Democratic governance and multinational corporations: Political regimes and inflows of foreign direct investment. International organization, 57(3), 587-616.

[10]. Odedokun, M. O. (1995). Evaluation of the Impacts of Military Regimes on the Economy: Multi-Country Evidence from the Sub-Sahara Africa. African Study Monographs, 16(3), 119-148.

[11]. Li, Q., \& Resnick, A. (2003). Reversal of fortunes: Democratic institutions and foreign direct investment inflows to developing countries. International organization, 57(1), 175-211.

[12]. Shah, Z., \& Ahmed, Q. M. (2003). The Determinants of Foreign Direct Investment in Pakistan: an Empirical Investigation. The Pakistan Development Review, 42(4), 697-714.

[13]. Abbas, Q., Akbar, S., Nasir, A. S., Ullah, H. A., \& Naseem, M. A. (2011). Impact of Foreign Direct Investment on Gross Domestic Product. Global Journal of Management and Business Research, 11 (8), 36-40.

[14]. Nawaz, T., Khan, M. A., Shah, M. A. A., \& Aleem, M. (2012). Impact of democratic/non-democratic regimes on foreign direct investment in Pakistan: Pre and post September 11, 2001 scenarios. Pakistan Journal of Commerce and Social Sciences (PJCSS), 6(1), 67-82.

[15]. Hsiao, C., \& Shen, Y. (2003). Foreign direct investment and economic growth: the importance of institutions and urbanization. Economic development and Cultural change, 51(4), 883-896.

[16]. Javed, R. M., Azim, P., \& Irshad, U. (2013). Determinants of Foreign direct investment: An empirical analysis of Pakistan. Glob. \& Sci. Issues, 1(3). 
[17]. Schneider, F., \& Frey, B. S. (1985). Economic and political determinants of foreign direct investment. World development, 13(2), 161-175.

[18]. Ercakar, M. E. (2011). Growth, foreign direct investment, trade and inflation: An empirical application on Turkey. Middle Eastern Finance and Economics, 9, 137-147.

[19]. Chowdhury, A., \& Mavrotas, G. (2006). FDI and growth: what causes what?. World economy, 29(1), 919.

[20]. Puri, S., \& Ritzema, T. (1999). Migrant worker remittances, micro-finance and the informal economy: prospects and issues. International Labour Organization.

[21]. Iwai, N., Thompson, S., \& Banerjee, P. (2004). Foreign Direct Investment and Education Investment in Developing Countries (No. 15643). University of Florida, International Agricultural Trade and Policy Center.

[22]. Wang, M., \& Wong, M. S. (2011). FDI, education, and economic growth: quality matters. Atlantic Economic Journal, 39(2), 103-115.
[23]. Shahbaz, M., Mateev, M., Abosedra, S., Nasir, M. A., \& Jiao, Z. (2021). Determinants of FDI in France: role of transport infrastructure, education, financial development and energy consumption. International Journal of Finance \& Economics, 26(1), 1351-1374.

[24]. Berrill, J., O’Hagan-Luff, M., \& van Stel, A. (2020). The moderating role of education in the relationship between FDI and entrepreneurial activity. Small Business Economics, 54(4), 1041-1059.

[25]. Alshubiri, F. N. (2020). Analysis of financial sustainability indicators of higher education institutions on foreign direct investment: Empirical evidence in OECD countries. International Journal of Sustainability in Higher Education.

[26]. World Bank. (2021). World Development Report 2021: Data for Better Lives. The World Bank.

[27]. Dickey, D. A., \& Fuller, W. A. (1981). Likelihood ratio statistics for autoregressive time series with a unit root. Econometrica: journal of the Econometric Society, 1057-1072.

[28]. Pesaran, M. H., Shin, Y., \& Smith, R. J. (2001). Bounds testing approaches to the analysis of level relationships. Journal of applied econometrics, 16(3), 289-326. 